\title{
A Instalação da COTIDE
}

$\bigcirc$

omo principal registro administrativo do primeiro trimestre. consignamos a instalação da Comissão do Tempo Integral e Dedicação Exclusiva (C.O.T.I.D.E.), cuja posse foi realizada nc Gabinete do Sr. Diretor-Geral do D.A.S.P. em 10 de março de 1966.

O Regime de Tempo Integral e Dedisação Exclusiva foi regulamentado pelo Decreto $n^{\circ} 57.774$ de 3 de fevereiro de 1966 em obediência ao estabelecido no $\S 5^{\circ}$ do art. $7^{\circ}$ da Lei $n^{\circ} 4.863$ de 29-11-65.

Iniciadas as atividades da nova Comissão, foi elaborado o seu regimento interno, consubstanciado no Decreto $n^{\circ} 58.095$ de 28 de março de 1966.

Integram a C.O.T.I.D.E. : um Plenário composto de 5 mem bros e uma Secretaria Executiva.

Os membros dêste organismo designados pelo Presidente da República por proposta do Diretor-Geral do D.A.S.P. e que exercerão mandato de 4 anos são os seguintes:

Dr. Eduardo Pinto Pessoa Sobrinho (Presidente) Agente Fiscal do Impôsto de Renda e Assessor do Ministro da Fazenda; ex-Técnico de Administração do D.A.S.P., ex-Diretor do Pessoal dos Ministérios da Fazenda e Justiça e Negócios Interiores; Autor de vários trabalhos de sua especialidade.

Edgard da Costa Amorim - Bacharel em Direito, Técnico de Administração do D.A.S.P. e Assessor do DiretorGeral dêste Departamento; ex-Diretor-Geral do D.A. do Ministério da Saúde, da D.O. do mesmo Ministério e da D.O. do D.A.S.P.

Itagildo Ferreira - Assistente Jurídico do Ministério da Agricultura; ex-Diretor-Geral do D.S.P. do Estado do Rio e da Divisão de Pessoal do Ministério da Agricultura; ex-Chefe do Gabinete do Ministro da Agricultura e ex-Assessor do Gabinete Civil da Presidência da República. 
Ottolmy Strauch - Bacharel em Direito e Técnico de Administração do D.A.S.P.; ex-Assistente Técnico do Gabinete Civil da Presidência da República; ex-Chefe dos Gabinetes do Ministro da Viação e Obras Públicas e da Presidência do B.N.D.E.

Heitor O'Dwyer - Engenheiro Agrônomo; Técnico de Administração; ex-Secretário-Geral da Viação Férrea Federal Leste Brasileiro; ex-Diretor da Divisão de Administração do D.N.E.F.

O programa de trabalho e a hierarquização das funções constituem os dois conceitos fundamentais em que se assentam as normas e critérios estabelecidos pela C.O.T.I.D.E. para racionalizar a implantação do Regime do Tempo Integral. 